\title{
The Golden jackal (Canis aureus) as an indicator animal for Trichinella britovi in Iran
}

\author{
Aliakbar Shamsian ${ }^{1}$, Edoardo Pozio ${ }^{2}$, Abdolmajid Fata ${ }^{1}, Z_{\text {Zahra Navi }}{ }^{\text {, }}$ and Elham Moghaddas ${ }^{1, *}$ \\ ${ }^{1}$ Department of Parasitology and Mycology, Faculty of Medicine, Mashhad University of Medical Sciences, Mashhad, Iran \\ ${ }^{2}$ Department of Infectious Diseases, Istituto Superiore di Sanità, Rome, Italy
}

Received 1 March 2018, Accepted 25 April 2018, Published online 10 May 2018

\begin{abstract}
Nematodes of the genus Trichinella are zoonotic parasites causing trichinellosis. In Iran, these parasites occur in several animal species and rare cases have been recorded in humans. To monitor the epidemiological pattern of these parasites in the Khorasan-e-Razavi province, Northeastern Iran, muscle tissues were collected from the tongues of roadkill animals between 2016 and 2017: 295 stray dogs, one red fox (Vulpes vulpes), 12 golden jackals (Canis aureus), and one wild boar (Sus scrofa). Trichinella spp. larvae were retrieved using the artificial digestion method and identified to the species level by multiplex PCR. Larvae identified as Trichinella britovi were detected in five stray dogs (1.7\%) and one golden jackal (8.3\%). The results confirm the circulation of T. britovi in animals of the Khorasan-e-Razavi province, as previously documented. A review of the literature on Trichinella spp. in animals in Iran showed that these parasites were previously detected in $20.02 \%$ and $0.04 \%$ of carnivore and omnivore mammals, respectively, and that golden jackals can be screened as indicator animals for these zoonotic nematodes. Convenient sampling of Trichinella susceptible roadkill animals may provide a suitable method of monitoring the circulation of these parasites within any given region.
\end{abstract}

Keywords: Trichinella britovi, Carnivore, Iran, Multiplex PCR, epidemiology

\begin{abstract}
Résumé- Le chacal doré (Canis aureus) comme animal indicateur de Trichinella britovi en Iran. Les nématodes du genre Trichinella sont des parasites zoonotiques causant la trichinellose. En Iran, ces parasites sont présents chez plusieurs espèces animales et des rares cas humains ont été enregistrés. Pour surveiller le profil épidémiologique de ces parasites dans la province de Khorasan-Razavi, au nord-est de l'Iran, les tissus musculaires ont été prélevés sur la langue de 295 chiens errants, un renard roux (Vulpes vulpes), 12 chacals dorés (Canis aureus) et un sanglier (Sus scrofa), tués sur les routes, en 2016-2017. Les larves de Trichinella spp. ont été récupérées en utilisant la méthode de digestion artificielle et identifiées au niveau de l'espèce par PCR multiplex. Des larves identifiées comme Trichinella britovi ont été détectées chez cinq chiens errants $(1,7 \%)$ et un chacal doré $(8,3 \%)$. Les résultats confirment la circulation de $T$. britovi chez les animaux de la province de Khorasan-Razavi, comme cela a été précédemment documenté. Une revue de la littérature sur Trichinella spp. chez les animaux d'Iran a montré que ces parasites avaient déjà été détectés chez 20,02\% et $0,04 \%$ des mammifères carnivores et omnivores, respectivement, et que les chacals dorés peuvent être criblés comme animaux indicateurs de ces nématodes zoonotiques. Un échantillonnage pratique des animaux sensibles à Trichinella tués sur les routes peut fournir une bonne méthode pour surveiller la circulation de ces parasites dans une région donnée.
\end{abstract}

\section{Introduction}

Trichinellosis is a foodborne parasitic zoonosis acquired by humans through the consumption of raw or semi-raw meat infected by Trichinella spp. from domestic

\footnotetext{
*Corresponding author: Mogaddase@mums . ac . ir
}

and wild swine and carnivores [11]. This disease is prevalent where these eating habits are widespread among the human population, such as those of Eastern Europe, South America, and South-East Asia [26]. Twelve taxa have been recognized within this genus so far, all of which are infectious to humans [32]. Most human infections are caused by Trichinella spiralis which is the most prevalent species in domestic and wild swine worldwide [26]. 
In Iran, human cases are rare due to religious regulations which prevent people from eating pork [18]. Pig breeding and the sale of pork by butchers are illegal in this country. However, some hunters do not respect religious regulations and slaughter wild boar and cook its meat in the same place where they hunted the animal. Sometimes, they sell wild boar meat to friends and relatives, a practice forbidden in Iran. Consequently, trichinellosis may unexpectedly emerge causing human outbreaks, like those observed in Italy [9]. In Iran in 1966, a human infection was suspected following the consumption of wild boar (Sus scrofa) meat [23]. More recently, a family outbreak of trichinellosis due to the consumption of wild boar meat was described near the Caspian Sea coast $[17,19]$. This and other outbreaks described in Algeria, Syria, and Turkey suggest that the Muslim population is at risk of acquiring trichinellosis [26].

Trichinella infections in wild animals have been described in Iran since 1967 [1]. These zoonotic nematodes have been detected with variable prevalence rates in carnivore mammals (brown bear, golden jackal, leopard, mongoose, stripped hyenas, jungle cat, red fox, stray dog) and omnivore mammals (Persian gerbil, wild boar) originating from six Iranian regions [1,4,13,20-22,24, $25,34]$.

Most of the epidemiological investigations on Trichinella in Iranian wildlife have focused on the prevalence of Trichinella spiralis in different host species. In recent years, molecular epidemiological studies have shown that the species circulating in Iran was Trichinella britovi [4,19,21,25], previously named Trichinella nelsoni $[28,35]$. T. spiralis has been documented only in a golden jackal from Khuzestan in the 1980s [35].

The high prevalence of infection detected in carnivores from Gilan, Mazandaran, Isfahan, Ardabil, Khuzestan and Khorasan-e-Razavi provinces requires monitoring of Trichinella spp. circulation in target host species. The aims of our study were to monitor the circulation of Trichinella parasites in carnivore mammals in the Khorasan-e-Razavi region after a period of five years from the previous survey [4], to assess the role of canids as indicator animals for Trichinella spp., to identify the etiological agent at the species level, and to review the literature on Trichinella spp. in Iranian animals.

\section{Materials and Methods}

\section{Study area and parasite collection}

Muscle samples from the tongue were collected from 309 roadkill animals, namely 295 stray dogs, 12 golden jackals (Canis aureus), one red fox (Vulpes vulpes), and one wild boar (Sus scrofa) during the period 2016-2017. Sampling was carried out in the areas surrounding the cities of Mashhad (36 $15^{\prime} 39^{\prime \prime}$ N, 59 $36^{\circ} 57^{\prime \prime}$ E), Sabzevar $\left(36^{\circ} 12^{\prime} 55^{\prime \prime} \mathrm{N}, 57^{\circ} 40^{\prime} 04^{\prime \prime} \mathrm{E}\right)$ and Neyshabur (36 $07^{\circ} 24^{\prime \prime} \mathrm{N}$, $\left.58^{\circ} 53^{\prime} 06^{\prime \prime} \mathrm{E}\right)$ in the Khorasan-e-Razavi province, Northeastern Iran (Figure 1).
Sampling and laboratory investigations were carried out under the control of the Iranian Environment Health Organization. Muscle samples collected in the field were preserved on ice during transportation to the Parasitology Laboratory, Medical Faculty of Mashhad University. Muscle samples $(0.5 \mathrm{~g})$ were screened by trichinoscopy at $40 \mathrm{x}$ magnification. Then, positive tongues were investigated by artificial digestion of $5 \mathrm{~g}$ per tongue in a pool of up to 10 animals, according to a published protocol [39]. When Trichinella larvae were detected in the sediment, $5 \mathrm{~g}$ of tongue from single animals were tested separately to identify the positive animal/s. Retrieved larvae were washed and preserved in a $0.5 \mathrm{~mL}$ conical tube with $90 \%$ ethyl alcohol for molecular identification to the species level.

\section{Molecular identification of Trichinella larvae}

Trichinella larvae, preserved in alcohol, were forwarded to the International Trichinella Reference Center (https:/ / trichinella.iss.it/) in Rome, Italy, for species identification. Single larvae were identified using a multiplex PCR technique, according to a published protocol [31].

\section{Results and Discussion}

Trichinella spp. larvae were detected in five stray dogs $(1.7 \%)$ from the areas surrounding Mashhad city and in one golden jackal (8.3\%) from the surroundings of Sabzevar city. The parasite load ranged from 3 to 5 larvae per gram. All the retrieved Trichinella larvae were molecularly confirmed as T. britovi.

The prevalence of $T$. britovi infections detected in the present study could be lower than the real prevalence in the investigated animals, since the initial search for Trichinella larvae used in this study was based on the use of trichinoscopy. It is well known that trichinoscopy has lower sensitivity than the digestion method, is strongly influenced by the analyst's experience, and does not allow the detection of non-encapsulated larvae of the Trichinella genus [39].

The literature search conducted in this study revealed that most Iranian authors had identified the Trichinella spp. larvae isolated from wild animals as Trichinella spiralis, because at that time the multiple species concept of the genus Trichinella was unconfirmed [29]. In 1983, four Trichinella isolates from Iranian golden jackals were identified by crossbreeding experiments as T. spiralis (one isolate from Sari near the Caspian Sea) and as T. nelsoni (three isolates from Khuzestan province) [35]. Today, the T. nelsoni [5] isolates from the Palearctic region are named T. britovi [28-30,32]. In 2009, a T. britovi isolate from a wild boar, which had been the source of infection to humans, had been erroneously identified as Trichinella murrelli $[17,19]$. Excluding this discrepancy, all Trichinella isolates from Iranian animals identified to the species level by molecular methods were identified as T. britovi. However, we must consider that Trichinella infections 


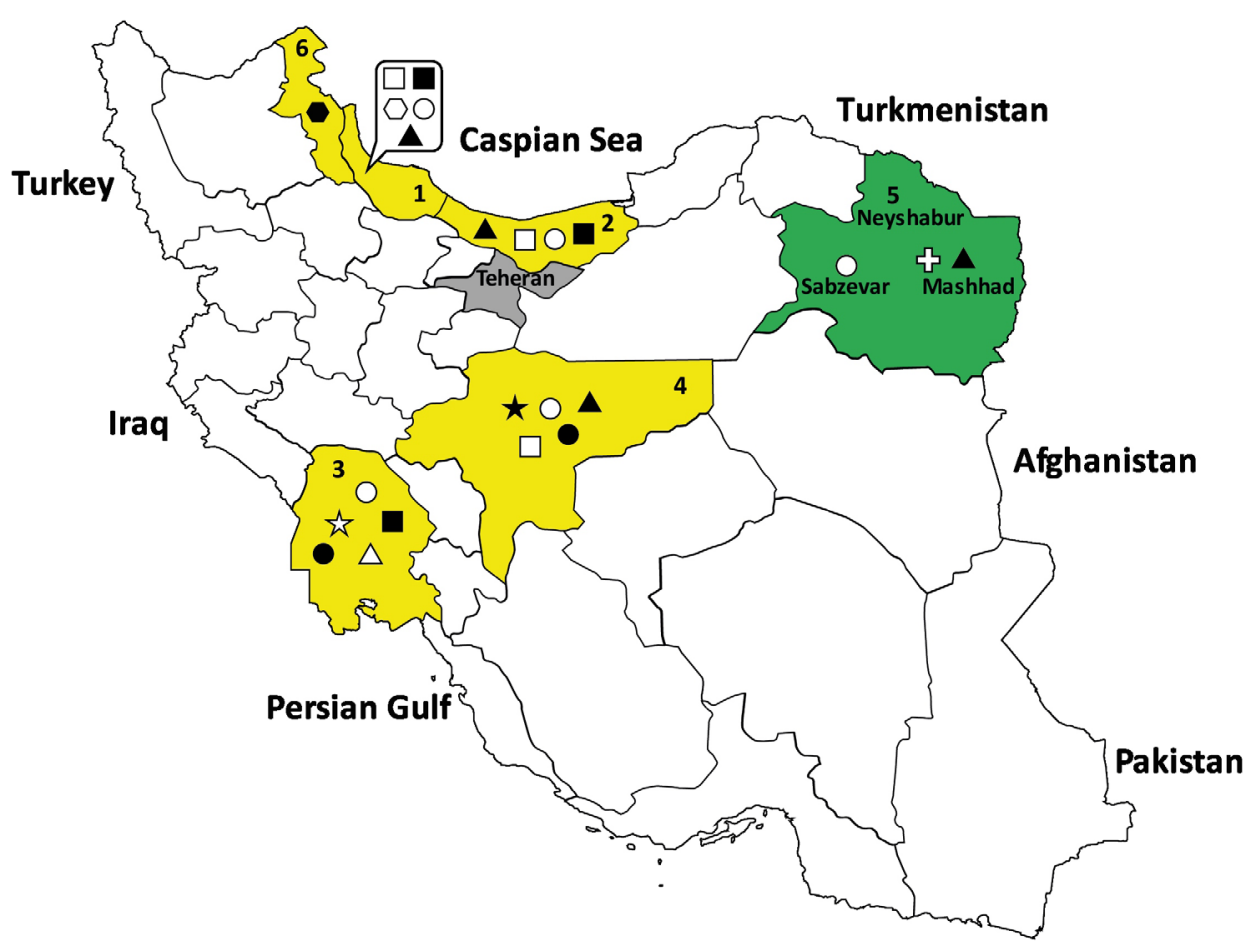

Figure 1. Map of Iran showing the six provinces (Gilan, 1; Mazandaran, 2; Khuzestan, 3; Isfahan, 4; Khorasan-e-Razavi, 5; and Ardabil, 6) where Trichinella spp. infected animals have been detected from 1967 to the present study. Khorasan-e-Razavi province, where the present study was carried out, is marked in green. In this province, animals tested for Trichinella spp. were collected from Mashhad, Sabzevar and Neyshabur cities. Trichinella britovi-positive animals were detected in the surroundings of Mashhad and Sabzevar cities. Teheran province is marked in grey. The five provinces marked in yellow show literature data. Each symbol of Trichinella spp.-infected animals represents from 1 to more than 100 positive heads: brown bear, open star; golden jackal, open circle; jungle cat, open hexagon; leopard, black hexagon; mongoose, open triangle; Persian gerbil, black star; red fox, open square; stripped hyena, black circle; stray dog, black triangle; wild boar, black square.

have been investigated only in six out of 31 Iranian provinces; it follows that the epidemiology of Trichinella in about $80 \%$ of the country is still unknown.

In Iran during a 50-year period (1967-2017), Trichinella parasites were screened for in 1,014 carnivore and 27,157 omnivore mammals, of which $203(20.02 \%)$ and $12(0.04 \%)$, respectively, tested positive (Table 1$)$. The difference in prevalence rates $(20.02 \%$ versus $0.04 \%)$ of infection between carnivore and omnivore mammals is consistent with epidemiological investigations carried out in other countries where T. britovi is known to circulate $[3,8,10,30,37]$. Epidemiological data on T. britovi in wild animals are supported by experimental data in domestic pigs, wild boars and red foxes, which show that $T$. britovi survives longer in carnivore than in omnivore mammals $[14,15,27]$. Trichinella spp. have also been detected in other carnivore mammals (brown bear, red fox, leopard, mongoose, jungle cat and stripped hyenas) and omnivore mammals (Persian gerbil), but the number of tested animals per species (Table 1 ) is too low to estimate their role in the epidemiology of this parasite.

In Iran, T. britovi has been documented in $2.97 \%$ of stray dogs $(20 / 673)$, and in $64.25 \%$ of golden jackals $(169 / 263)$ collected in five provinces (Table 1$)$. These data suggest that the golden jackal can be a good indicator animal for the circulation of Trichinella spp. in Iran, due to its scavenger behavior and adaptation to different habitats, including the domestic habitat [36]. The convenient sampling of roadkill animal carcasses may represent an easy and inexpensive method of monitoring the circulation of this zoonotic parasite. The scavenger behavior of this canid allows golden jackals to be considered a sentinel for the circulation of some zoonotic pathogens, including Trichinella as already observed in other countries $[6,7,38]$.

Human trichinellosis has been documented in seven individuals who had consumed wild boar meat in Iran $[17,18]$. However, this disease may be under-recognized due to the low numbers of ingested larvae and the lack of experience of physicians in detecting what is essentially a rare disease in Iran. In Islamic countries, butchers and hunters and their relatives can be at risk of this disease as shown by the detection of anti-Trichinella antibodies in $2.2 \%$ of butchers and hunters in northern Iran [16]. In Iran, hunting is a common sport from October to April. Hunters frequently grill meat immediately after hunting, a cooking method that frequently does not kill Trichinella larvae, especially those near bones. Even though trichinellosis is extremely rare in Islamic countries, sporadic outbreaks have been documented among certain communities belonging to other religions and cultures in Egypt, Lebanon, Israel, and Syria, or involving Muslims inadvertently like 
Table 1. Trichinella spp. in animals in Iran from 1973 to the present study.

\begin{tabular}{|c|c|c|c|}
\hline Host & Province & N. positive/tested (\%) & Reference \\
\hline$\overline{\text { Badger (Meles meles) }}$ & Gilan and Mazandaran & $0 / 1$ & {$[22]$} \\
\hline Brown bear (Ursus arctos) & Khuzestan & $1 / 16$ & {$[22]$} \\
\hline Domestic cat & Gilan and Mazandaran & $0 / 1$ & {$[22]$} \\
\hline Domestic dog & Gilan and Mazandaran & $0 / 1$ & {$[22]$} \\
\hline \multirow[t]{8}{*}{ Golden jackal (Canis aureus) } & Gilan and Mazandaran & $38 / 63(60.31)$ & {$[22]$} \\
\hline & Isfahan & $10 / 18(55.55)$ & {$[34]$} \\
\hline & Khuzestan & $11 / 25(44.00)^{\mathrm{a}}$ & {$[20]$} \\
\hline & Gilan and Mazandaran & $105 / 125(84.00)$ & {$[13]$} \\
\hline & Khuzestan & $1 / 1^{\mathrm{b}}$ & {$[35]$} \\
\hline & Mazandaran & $1 / 1^{\mathrm{c}}$ & {$[35]$} \\
\hline & Khuzestan & $2 / 18(11.11)$ & {$[21]$} \\
\hline & Khorasan-e-Razavi & $1 / 12(8.33)$ & present study \\
\hline \multirow[t]{2}{*}{ Insectivores } & Gilan and Mazandaran & $0 / 20 \mathrm{~d}$ & {$[22]$} \\
\hline & Gilan and Mazandaran & $0 / 26^{\mathrm{e}}$ & {$[13]$} \\
\hline Jungle cat (Felis chaus) & Khuzestan & $0 / 4$ & {$[20]$} \\
\hline Lagomorpha $^{\mathrm{f}}$ & Gilan and Mazandaran & $0 / 28$ & {$[13]$} \\
\hline Leopard (Panthera pardus saxicolor) & Ardabil & $1 / 1^{\mathrm{c}}$ & {$[25]$} \\
\hline Mongoose (Herpestes auropunctatus) & Khuzestan & $3 / 10$ & {$[24]$} \\
\hline \multirow[t]{2}{*}{ Persian gerbil (Meriones persicus) } & Isfahan & $1 / 29(3.44)$ & {$[34]$} \\
\hline & Isfahan & $2 / 18(11.11)$ & {$[34]$} \\
\hline \multirow[t]{5}{*}{ Red fox (Vulpes vulpes) } & Khuzestan & $0 / 6$ & {$[20]$} \\
\hline & Gilan and Mazandaran & $3 / 10$ & {$[13]$} \\
\hline & Khorasan-e-Razavi & $0 / 2$ & {$[4]$} \\
\hline & Khorasan-e-Razavi & $0 / 1$ & present study \\
\hline & Isfahan & $1 / 1$ & {$[34]$} \\
\hline \multirow[t]{2}{*}{ Stripped hyena (Hyena hyena) } & Khuzestan & $1 / 1$ & {$[20]$} \\
\hline & Khorasan-e-Razavi & $0 / 2$ & {$[4]$} \\
\hline \multirow[t]{10}{*}{ Stray dog } & Teheran & $0 / 21$ & {$[20]$} \\
\hline & Isfahan & $2 / 10$ & {$[34]$} \\
\hline & Khuzestan & $0 / 37$ & {$[20]$} \\
\hline & Isfahan & $1 / 75(1.4)$ & {$[40]$} \\
\hline & Khorasan-e-Razavi & $3 / 120(2.5)$ & {$[4]$} \\
\hline & Khuzestan & $0 / 14$ & {$[21]$} \\
\hline & Khorasan-e-Razavi & $5 / 295(1.69)$ & present study \\
\hline & Gilan and Mazandaran & $2 / 4,950(0.04)$ & {$[1]$} \\
\hline & Gilan and Mazandaran & $5 / 21,143(0.02)$ & {$[22]$} \\
\hline & Khuzestan & $1 / 4$ & {$[20]$} \\
\hline \multirow[t]{4}{*}{ Wild boar (Sus scrofa) } & Gilan & $1 / 1^{\mathrm{g}}$ & {$[17]$} \\
\hline & Khorasan-e-Razavi & $0 / 26$ & {$[4]$} \\
\hline & Mazandaran & $2 / 35(5.7) \mathrm{Tb}$ & {$[33]$} \\
\hline & Khorasan-e-Razavi & $0 / 1$ & present study \\
\hline \multirow[t]{4}{*}{ Wild rodents } & Gilan and Mazandaran & $0 / 30^{\mathrm{h}}$ & {$[22]$} \\
\hline & Isfahan & $0 / 93^{\mathrm{i}}$ & {$[34]$} \\
\hline & Gilan and Mazandaran & $0 / 746^{1}$ & {$[13]$} \\
\hline & Khorasan-e-Razavi & $0 / 25^{\mathrm{m}}$ & {$[4]$} \\
\hline
\end{tabular}

a larvae from two golden jackals were successively identified as Trichinella britovi (see [35]);

b the isolate has been identified as Trichinella spiralis;

c the isolate has been identified as Trichinella britovi;

d 20 greater white-toothed shrew (Crocidura russula);

e 13 hedgehogs (Erinaceus europeus) and 13 bicolored shrew (Crocidura leucodon);

f 7 hares (Lepus capensis) and 21 pika (Ochotona rufescens);

g erroneously identified as Trichinella murrelli (see [19]);

$\mathrm{h}$ house mouse (Mus musculus), wood mouse (Apodemus sylvaticus) and black rat (Rattus rattus);

i 43 house mouse (Mus musculus), 9 grey hamster (Cricetulus migratorius), 15 short-tailed bandicoot rat (Nesokia indica), 13 Sundevall's jird (Meriones crassus), 2 wood mouse (Apodemus sylvaticus), and 11 great gerbils (Rhombomys opimus);

${ }^{1} 56$ small five-toed jerboa jerboas (Allactaga elater), 4 dormice (Glis glis), 160 house mice (Mus musculus), 206 wood mice (Apodemus sylvaticus), 10 Indian scaly tailed murine rats (Nesokia indica), 7 rats (Rattus ratoides), 108 hamsters (Cricetulus migratorius and Calomyscus bailwardi), 69 voles (Microtus transcapicus, M. socialis, M. arvalis and M. nivalis), 130 gerbils (Meriones persicus, M. crassus, and Rhombomys opimus);

m species unknown. 
in Turkey $[2,12,26]$. It follows that public health, veterinary services and hunter's associations should be aware of the circulation of these zoonotic parasites in their regions to educate hunters and consumers on the risk of acquiring this serious disease.

\section{Ethics}

The study adhered to the tenets of the Declaration of Helsinki and was approved by the Ethics Committee at Mashhad University of Medical Sciences (Ethical code: IR. MUMS.fm.REC.1399.522).

\section{Funding}

This work was supported by Mashhad University of Medical Sciences (Project grant 940898). The Mashhad University of Medical Sciences did not have any role in the design and execution of this investigation. The molecular identification of Trichinella larvae was supported by the 2017 funds of the European Commission (DG SANTE) for the European Union Reference Laboratory for Parasites, Rome, Italy.

\section{Authors' contributions}

AS and AF designed and coordinated the study. EM drafted and revised the manuscript. EP identified the parasite to the species level, performed the data analysis, and revised the manuscript. All authors read and approved the final manuscript.

Acknowledgements. We thank Majid Derakhshani, who collected the samples.

\section{Conflict of Interest}

There are no conflicts of interest to declare.

\section{References}

1. Afshar A, Jahfarzadeh Z. 1967. Trichinosis in Iran. Annals of Tropical Medicine and Parasitology, 61, 349-351.

2. Akkoc N, Kuruuzum Z, Akar S, Yuce A, Onen F, Yapar N, Ozgenc O, Turk M, Ozdemir D, Avci M, Guruz Y, Oral AM, Pozio E. 2009. A large-scale outbreak of trichinellosis caused by Trichinella britovi in Turkey. Zoonoses and Public Health, 56(2), 65-70.

3. Aoun O, Lacour SA, Levieuge A, Marié JL, Vallée I, Davoust B. 2012. Screening for Trichinella britovi infection in red fox (Vulpes vulpes) and wild boar (Sus scrofa) in southeastern France. Journal of Wildlife Diseases, 48(1), 223-225.

4. Borji H, Sadeghi H, Razmi G, Pozio E, La Rosa G. 2012. Trichinella infection in wildlife of northeast of iran. Iran Journal of Parasitology, 7(4), 57-61.

5. Britov V, Boev S. 1972. Taxonomic rank of various strains of Trichinella and their circulation in nature. Vestnik Akademii Naitk Kazakhskoi SSR, 28, 27-32.
6. Ćirović D, Teodorović V, Vasilev D, Marković M, Ćosić N, Dimitrijević M, Klun I, Djurković-Djaković O. 2015. A large-scale study of the Trichinella genus in the golden jackal (Canis aureus) population in Serbia. Veterinary parasitology, 212(3), 253-256.

7. Dmitric M, Vidanovic D, Vaskovic N, Matovic K, Sekler M, Debeljak Z, Karabasil N. Trichinella infections in red foxes (Vulpes vulpes) and golden jackals (Canis aureus) in six districts of Serbia. Journal of Zoo and Wildlife Medicine, 48(3), 703-707.

8. Erster O, Roth A, King R, Markovics A. 2016. Molecular characterization of Trichinella species from wild animals in Israel. Veterinary parasitology, 231, 128-131.

9. Fichi G, Stefanelli S, Pagani A, Luchi S, De Gennaro M, Gómez-Morales MA, Selmi M, Rovai D, Mari M, Fischetti R, Pozio E. Trichinellosis outbreak caused by meat from a wild boar hunted in an Italian region considered to be at negligible risk for Trichinella. Zoonoses and Public Health, $62(4), 285-291$

10. Garbarino C, Interisano M, Chiatante A, Marucci G, Merli E, Arrigoni N, Cammi G, Ricchi M, Tonanzi D, Tamba M, La Rosa G, Pozio E. 2017. Trichinella spiralis a new alien parasite in Italy and the increased risk of infection for domestic and wild swine. Veterinary Parasitology, 246, 1-4.

11. Gottstein B, Pozio E, Nockler K. 2009. Epidemiology, diagnosis, treatment, and control of trichinellosis. Clinical Microbiology Review, 22(1), 127-145.

12. Haim M, Efrat M, Wilson M, Schantz PM, Cohen D, Shemer J. 1997. An outbreak of Trichinella spiralis infection in southern Lebanon. Epidemiology and Infection, 119(3), 357-362.

13. Hamidi A. 1979. Trichiniasis among the animals in North Eastern Iran, 1969, 1976, 1977. Bulletin de la Société de Pathologie Exotique et de ses Filiales, 72, 254-257.

14. Kapel CM. 2001. Sylvatic and domestic Trichinella spp. in wild boars; infectivity, muscle larvae distribution, and antibody response. Journal of Parasitology, 87(2), 309-314.

15. Kapel CM, Gamble HR. 2000. Infectivity, persistence, and antibody response to domestic and sylvatic Trichinella spp. in experimentally infected pigs. International Journal for Parasitology, 30(2), 215-221.

16. Khazan H, Rostami A, Kazemi B, Kia EB, Taghipour N. 2018. Seroprevalence of Trichinella spp. infections among at-risk people in Mazandaran province, northern Iran. Iranian Journal of Parasitology,13(1), 219.

17. Kia E, Meamar A, Zahabiun F, Mirhendi H. 2009. The first occurrence of Trichinella murrelli in wild boar in Iran and a review of Iranian trichinellosis. Journal of Helminthology, 83(4), 399-402.

18. Mahdavi M. 2009. Trichinellosis in Iran. Indian Journal of Public Health, 38(1), 131-133.

19. Marucci G, La Rosa G, Pozio E. 2010. Incorrect sequencing and taxon misidentification: an example in the Trichinella genus. Journal of Helminthology, 84, 336-339.

20. Massoud J. 1978. Trichinellosis in carnivores in Iran. In: Kim CW, Pawlowski ZS (Eds), Trichinellosis. Hanover, New Hampshire, University Press of New England, 551-554.

21. Mirjalali H, Rezaei S, Pozio E, Naddaf SR, SalahiMoghaddam A, Kia EB, Shahbazi F, Mowlavi Gh. 2014. Trichinella britovi in the jackal Canis aureus from southwest Iran. Journal of Helminthology, 88(4), 385-388.

22. Mobedi I, Arfaa F, Madadi H, Movafagh K. 1973. Sylvatic focus of trichiniasis in the Caspian region, Northern Iran. American Journal of Tropical Medicine and Hygiene, 22, $720-722$.

23. Moin M. 1966. First report of trichinosis in humans in Iran. Tehran University Medical Journal, 5, 259-267. 
24. Mowlavi G, Massoud J, Rokni M. 2000. Herpestes auropunctatus as a new reservoir host of Trichinella spiralis in Iran. Iranian Journal of Public Health, 29, $67-70$.

25. Mowlavi G, Marucci G, Mobedi I, Zahabiioon F, Mirjalali H, Pozio E. 2009. Trichinella britovi in a leopard (Panthera pardus saxicolor) in Iran. Veterinary Parasitology, 164, 350-352.

26. Murrell KD, Pozio E. 2011. Worldwide occurrence and impact of human trichinellosis, 1986-2009. Emerging Infection Diseases, 17(12), 2194-2202.

27. Nöckler K, Serrano FJ, Boireau P, Kapel CM, Pozio E. 2005. Experimental studies in pigs on Trichinella detection in different diagnostic matrices. Veterinary Parasitology, 132 (1-2), 85-90.

28. Pozio E, La Rosa G, Murrell KD, Lichtenfels JR. 1992. Taxonomic revision of the genus Trichinella. Journal of Parasitology, 78, 654-659.

29. Pozio E, Murrell KD. 2006. Systematics and epidemiology of Trichinella. Advances in Parasitology, 63, 367-439.

30. Pozio E, Rinaldi L, Marucci G, Musella V, Galati F, Cringoli G, Boireau P, La Rosa G. 2009. Hosts and habitats of Trichinella spiralis and Trichinella britovi in Europe. International Journal for Parasitology, 39(1), 71-79.

31. Pozio E, La Rosa G. 2010. Trichinella. Molecular detection of foodborne pathogens. Liu D (Ed), Molecular Detection of Foodborne Pathogens, CRC Press, Taylor \& Francis Group, Boca Raton, 851-863.
32. Pozio E, Zarlenga DS. 2013. New pieces of the Trichinella puzzle. International Journal for Parasitology, 43(12-13), 983-997.

33. Rostami A, Khazan H, Kazemi B, Kia EB, Bandepour M, Taghipour N, Mowlavi G. 2017. Prevalence of Trichinella spp. infections in hunted wild boars in northern Iran. Iran Journal of Public Health, 46(12), 1712-1719. 16.

34. Sadighian A, Arfaa F, Movafagh K. 1973. Trichinella spiralis in carnivores and rodents in Isfahan, Iran. Journal of Parasitology, 59, 986

35. Shaikenov B, Boev S. 1983. Distribution of Trichinella species in the Old World. Wiadomosci Parazytologiczne, 29, 596-608.

36. Sillero-Zubiri C, Hoffman M, MacDonald DW. 2004 Canids: Foxes, Wolves, Jackals and Dogs - Status Survey and Conservation Action Plan, IUCN/SSC Canid Specialist Group, Gland, Switzerland and Cambridge, UK: 1-430.

37. Széll Z, Marucci G, Pozio E, Sréter T. Echinococcus multilocularis and Trichinella spiralis in golden jackals (Canis aureus) of Hungary. Veterinary parasitology, 197, 393-396.

38. Watier-Grillot S, Vallée I, Lacour S, Cana A, Davoust B, Marié JL. 2011. Strayed dogs sentinels of Trichinella britovi infection in Kosovo. Parasite, 18(3), 281-283.

39. World Organization for Animal Health. 2008. Manual of diagnostic tests and vaccines for terrestrial animals. Bulletin de l'Office International des Épizooties, 1092-1106.

40. Yousefi H. 2003. A case of trichinellosis among stray dogs in Isfahan. $4^{\text {th }}$ Congress of Parasitology, Mashad, Iran, 80 .

Cite this article as: Shamsian A, Pozio E, Fata A, Navi Z, Moghaddas E. 2018. The Golden jackal (Canis aureus) as an indicator animal for Trichinella britovi in Iran. Parasite 25, 28

Reviews, articles and short notes may be submitted. Fields include, but are not limited to: general, medical and veterinary parasitology; morphology, including ultrastructure; parasite systematics, including entomology, acarology, helminthology and protistology, and molecular analyses; molecular biology and biochemistry; immunology of parasitic diseases; host-parasite relationships; ecology and life history of parasites; epidemiology; therapeutics; new diagnostic tools.

All papers in Parasite are published in English. Manuscripts should have a broad interest and must not have been published or submitted elsewhere. No limit is imposed on the length of manuscripts.

Parasite (open-access) continues Parasite (print and online editions, 1994-2012) and Annales de Parasitologie Humaine et Comparée (1923-1993) and is the official journal of the Société Française de Parasitologie. 